\title{
Former Corporate Officers and Employees in the Context of the Collective Entity and Act of Production Doctrines
}

\author{
Alice W. Yao $\dagger$
}

Courts have divided over whether a former employee of a corporation can be forced to produce documents in response to a subpoena when the production of the documents would implicate the employee in a crime. This question turns on whether a former corporate employee or officer maintains a representative relationship with the corporation following his employment, or if his ability to represent the corporation terminates with his employment.

While it is well-established that the government may not compel an individual to give testimony that would be self-incriminating, the Fifth Amendment privilege against self-incrimination typically does not apply to the contents of business documents that the government requests through a subpoena.' For example, the government may subpoena business records that a defendant created for his own benefit that reveal incriminating information. In contrast, a prosecutor could not call that defendant before a grand jury and force him to testify against himself regarding those documents. This seemingly artificial distinction under the Fifth Amendment is based on the interpretation of the word "compel." Because the government did not compel the defendant to create the business records, it does not "compel" the defendant to "testify" against himself. However, when the government forces the defendant to give oral testimony as to the information contained in those records, such testimony is considered compelled and thus protected by the Fifth Amendment. Chicago.

$\dagger$ S.B. 1999, Massachusetts Institute of Technology; J.D. Candidate 2002, The University of

1 The exact nature of the Fifth Amendment privilege against self-incrimination is not pertinent to this analysis. For a more detailed discussion of the application of the privilege to the contents of documents, see Robert P. Mosteller, Simplifying Subpoena Law: Taking the Fifth Amendment Seriously, 73 Va L Rev 1, 49-74 (1987) (listing exceptions to the general rule that contents of corporate documents are not protected by the Fifth Amendment privilege against self-incrimination, and specifically addressing the artificial entities exception and the required records exception).

2 Fisher v United States, 425 US 391, 397 (1976), quoting Perlman v United States, 247 US 7, 15 (1918) ("The Court has held repeatedly that the Fifth Amendment is limited to prohibiting the use of 'physical or moral compulsion' exerted on the person asserting the privilege.").

3 United States v Doe, 465 US 605, 610 (1984) ("As we noted in Fisher, the Fifth Amendment protects the person asserting the privilege only from compelled self-incrimination. Where 
But in some cases the mere act of producing documents in response to a subpoena reveals incriminating information, and in these instances the subpoena may implicate the Fifth Amendment privilege against self-incrimination. The Supreme Court has developed an analytical framework for all documentary subpoenas that turns on the testimonial and incriminating nature of the act of production. ${ }^{4}$ The act of production may communicate to the grand jury or prosecutor the individual's possession of the subpoenaed documents, as well as his knowledge regarding their existence and authenticity. Thus, the incriminating nature of the act of production is distinct from the contents of the document itself. Instead, the validity of the documentary subpoena turns on the potentially incriminating implications of the actual act of producing the documents.

However, according to the Supreme Court, a collective or artificial entity does not hold any privilege against self-incrimination. ${ }^{6}$ This doctrine, known as the collective entity doctrine, relies on the notion that a corporation is an entity independent of those who comprise it. The doctrine states that if an employee holds corporate records as a representative of an entity independent of himself (for example, a corporation), then he can be compelled to produce those documents because he would be acting on behalf of the corporation rather than himself. In order to preserve the individual's privilege against selfincrimination, the prosecutor may not use the individual's act of production against him individually, but instead must attribute the act of production to the corporation as a whole.

The act of production doctrine generally applies in all cases involving documentary subpoenas. However, where the target of the subpoena is a collective entity or a representative of such an entity, the collective entity doctrine operates as an exception to the general rule. Thus, where the collective entity doctrine applies, a prosecutor can obtain requested documents belonging to an entity, but cannot identify the individual who produced the incriminating documents. Where the collective entity doctrine does not apply, however, the act of production doctrine precludes the production of documents altogether, thereby denying a prosecutor potentially incriminating evidence.

the preparation of business records is voluntary, no compulsion is present.") (citation omitted).

4 See Fisher, 425 US at 410 ("The act of producing evidence in response to a subpoena... $\mathrm{f}_{\mathrm{i}}$ as communicative aspects.").

5 Id ("Compliance with the subpoena tacitly concedes the existence of the papers demanded and their possession or control by the taxpayer. It also would indicate the taxpayer's belief that the papers are those described in the subpoena.").

6 Braswell $v$ United States, 487 US 99, 102 (1988) (noting that "it is well established that such artificial entities [corporations] are not protected by the Fifth Amendment"). 
A growing circuit split demonstrates that the role of these two doctrines in the context of former corporate employees is unclear. The Eleventh Circuit, relying on the nature of the documents sought, held that under the collective entity doctrine the government can compel a former employee to produce corporate documents that remain in his personal possession following the termination of his employment. ${ }^{7}$ In contrast, the Second Circuit ruled that an employee no longer acts as a representative of his former employer following termination, and thus the government may be precluded from obtaining documents if the act of production might incriminate the former employee.

This Comment resolves the circuit split by looking to principles of corporate law. More specifically, this Comment argues that the collective entity doctrine should apply to former employees in cases where there is a continuing fiduciary relationship following the termination of employment. For instance, following the dissolution of a corporation, the former business's directors have fiduciary obligations to the corporation until the resolution of all remaining corporate affairs.' Consequently, these directors maintain a representative relationship with that corporation, and the collective entity doctrine should govern. However, where there is no such continuing fiduciary or other such obligation, the act of production doctrine should apply in order to protect the individual's fundamental privilege against selfincrimination. Thus, in the context of a continuing fiduciary obligation, as with current employees and officers, the documents requested may be produced, but the act of production may not be attributed to any individual. If there is no continuing obligation on the part of the former employee or officer, then the documents may not be produced by virtue of the potentially incriminating nature of the act of production.

Part I of this Comment provides a brief history of the Fifth Amendment privilege against self-incrimination in the context of documentary subpoenas. It also explains how the act of production and collective entity doctrines operate to protect this privilege. Part II describes the different approaches that courts have taken to deter-

7 In re Grand Jury Subpoena Dated Nov 12, 1991, 957 F2d 807, 812-13 (11th Cir 1992) (holding that a former corporate official whose employment was terminated after acquiring custody of corporate documents is required to produce those documents under the collective entity doctrine).

8 In re Three Grand Jury Subpoenas Duces Tecum Dated Jan 29, 1999, 191 F3d 173, 181-84 (2d Cir 1999) (holding that three former officers of a corporation could not be compelled to produce corporate documents in their possession pursuant to the collective entity doctrine because their capacity to represent the corporation as agents had already been terminated).

9 William Meade Fletcher, 19 Fletcher Cyclopedia of the Law of Private Corporations $\S 3: 150$ at 453 (Callaghan perm ed 1988) (noting that "statutes will usually provide that, upon the dissolution, the directors of the corporation shall have charge of the work of liquidation and distribution"). 
mine whether former corporate employees can be compelled to produce potentially self-incriminating corporate documents. Part III proposes a new approach to the analysis by relying on principles of corporate law to determine whether the former employee and the corporation have a continuing representative relationship that would dictate the application of the collective entity doctrine.

\section{The Act of Production ANd Collective ENTITy DoctRines}

The Fifth Amendment states that "[n]o person shall be ... compelled in any criminal case to be a witness against himself." The purpose of the Fifth Amendment privilege is to prevent the use of legal compulsion to force the accused to make sworn testimony that would be used to incriminate him. ${ }^{1}$ An individual must show three distinct elements to establish that his privilege against self-incrimination is being infringed: (1) that there is testimony; (2) that the testimony is compelled; and (3) that the testimony is incriminating. ${ }^{12}$ The Court's current jurisprudence holds that the Fifth Amendment privilege against self-incrimination does not protect the contents of business documents, but rather only the act of production itself. ${ }^{13}$ The Court's distinction between the act of production and the contents promotes the Fifth Amendment aim of protecting the accused from potentially incriminating himself by averring the existence, the authenticity, and his possession of the documents requested.

10 US Const Amend V.

11 Doe v United States, 487 US 201, 212 (1988).

12 See Fisher $v$ United States, 425 US 391, 410 (1976) (emphasizing that whether an infringement of the privilege against self-incrimination has occurred turns on whether there is compulsion, whether the act of production is testimonial, and whether it is incriminating).

13 Prior to Fisher, the Court had referred to the Fifth Amendment privilege against selfincrimination as protecting the contents of personal documents. See Boyd v United States, 116 US 616,630 (1886) (characterizing the Fourth and Fifth Amendments as protecting personal security and privacy). But the Court changed the direction of this jurisprudence in Fisher. As Justice Brennan explained in his concurrence in Fisher: "History and principle teach that the privacy protected by the Fifth Amendment extends not just to the individual's immediate declarations, oral or written, but also to his testimonial materials in the form of books and papers." 425 US at 418. However, the Fisher majority focused on the fact that the subpoena served on the accused did not compel oral testimony or require the accused to restate, repeat, or affirm the truth of the documents sought, rather than focusing on the question of whether the documents contained private information. See Fisher, 425 US at 400 (explaining that the Fifth Amendment protects citizens against self-incrimination but not against the disclosure of private information generally). Justice O'Connor sought to make this distinction explicit in United States $v$ Doe:

I write ... just to make explicit what is implicit in the analysis of [the majority's] opinion: that the Fifth Amendment provides absolutely no protection for the contents of private papers of any kind. The notion that the Fifth Amendment protects the privacy of papers originated in Boyd v. United States ... but our decision in Fisher v. United States ... sounded the death knell for Boyd.

465 US 605, 618 (1984) (citations omitted). 


\section{A. The Act of Production Doctrine}

The Court espoused the act of production doctrine in Fisher $v$ United States, ${ }^{14}$ which established that "the Fifth Amendment would not be violated by the fact alone that the papers on their face might incriminate [the petitioner], for the privilege protects a person only against being incriminated by his own compelled testimonial communications." "The Court held in Fisher that an attorney was required to produce his client's accountant's documents because the accountant's documents had been created without any government compulsion. Although the act of producing the documents had communicative aspects of its own, the Court reasoned that the act would not involve incriminating testimony within the protection of the Fifth Amendment," because the documents' existence was a "foregone conclusion." Even if the act of production would usually trigger the privilege against selfincrimination, the Court explained, the government may still compel the production of the documents if it can show that the act of production itself would not add to the government's information about the case. ${ }^{18}$ If the potentially incriminating aspects of the act of production are a "foregone conclusion," then "[u]nder these circumstances by enforcement of the summons "no constitutional rights are touched. The question is not of testimony but of surrender." "Thus, according to the Fisher Court, an individual is permitted to assert his personal privilege against self-incrimination only if the act of producing the documents itself might be incriminating. ${ }^{20}$ An individual may not assert the Fifth Amendment purely because the contents of the documents requested might be incriminating. ${ }^{21}$

14425 US 391 (1976).

15 Id at 409.

16 In Fisher, the government had prior knowledge of the existence of the documents requested, and production of the documents by the defendant would not be used for authentication purposes. Id at 413 (noting that the "taxpayer did not prepare the papers and could not vouch for their accuracy"). See also id at 402 (holding that "compelled production of documents from an attorney does not implicate" a taxpayer's Fifth Amendment privilege).

17 Id at 411.

18 Id at 411-12 (noting that because the existence and location of the requested documents were a foregone conclusion, the tacit admissions related to the act of production were not sufficient to implicate the privilege against self-incrimination).

19 Id at 411, quoting In re Harris, 221 US 274, 279 (1911). More specifically, the foregone conclusion doctrine states that the government must show: (1) the government is not relying on the truth-telling aspect of the act of production; (2) the witness adds little or nothing to the government's already established knowledge about the existence and location of the papers by conceding his possession of the papers; (3) existence and possession are not critical to the case. See Mosteller, 73 Va L Rev at 30 (cited in note 1 ).

20 See Fisher, 425 US at 410.

21 See id. The act of production doctrine applies to all cases involving the compelled production of documents, while the collective entity doctrine only applies in the corporate context. Braswell v United States, 487 US 99, 109-10 (1988) (noting that although "the act of production 
This perhaps artificial distinction between the act of production and contents of the document rests on the fact that the individual voluntarily created the document being sought. Consequently, under the Fifth Amendment, the individual was not "compelled" to create whatever information is within the document. ${ }^{22}$ As the Supreme Court explained, "[T]he Fifth Amendment protects against "compelled selfincrimination, not [the disclosure of] private information." ${ }^{23}$ Therefore, the government may compel the production of papers that an individual prepares in a private capacity.

The act of production doctrine addresses the policy concern that the act of producing certain documents requested in a subpoena duces tecum may cause the witness to incriminate himself in a number of ways. The act of production may communicate that: "i) documents responsive to a given subpoena exist; ii) they are in the possession or control of the subpoenaed party; iii) the documents provided in response to the subpoena are authentic; and iv) the responding party believes that the documents produced are those described in the subpoena."2s

The Court most recently rearticulated the principles underlying the doctrine in United States $v$ Hubbell.$^{26}$ The Court held that the act of production in response to a broad grand jury subpoena ${ }^{27}$ would be self-incriminating not because of the contents of the documents, but because responding to the subpoena would aver the witness's possession of such documents, as well as the witness's belief that these were the documents sought. ${ }^{28}$ The Supreme Court reemphasized the Fisher

privilege is available without regard to the entity whose records are being sought," the agents of a corporation responding to a subpoena duces tecum are ultimately acting in a representative capacity and thus cannot assert the Fifth Amendment privilege against self-incrimination). Thus, the Court has recognized the attributed act theory-when an individual produces documents in response to a subpoena as a representative of a corporation, the act of producing the documents is not attributed to the individual, but rather to the corporation as a whole. Id at 117-18. As a result, an individual acting in a representative capacity for a corporation may never refuse to produce corporate documents that are under his custody-but the government may not use the fact that he (as an individual) actually produced the documents. Id.

22 United States $v$ Doe, 465 US 605, 610 (1984). See note 3 and accompanying text.

23 Fisher, 425 US at 401, quoting United States v Nobles, 422 US 225, 233 n 7 (1975).

24 Doe, 465 US at 618 (O'Connor concurring).

25 United States v Hubbell, 167 F3d 552, 567-68, 575-81 (DC Cir 1999), affd, 530 US 27 (2000) (remanding for a determination of whether the government had the requisite knowledge so that compelled production of documents would not infringe the defendant's Fifth Amendment rights).

26530 US $27(2000)$.

27 The district court characterized the subpoena as "the quintessential fishing expedition." Id at 32, quoting United States v Hubbell, 11 F Supp 2d 25, 37 (D DC 1998).

28 See Hubbell, 530 US at 45 ("Given our conclusion that respondent's act of production had a testimonial aspect ... respondent could not be compelled to produce those documents."). 
principle that the potentially self-incriminating nature of the act of production is the critical issue in Fifth Amendment analysis. ${ }^{29}$

The analysis that courts use to determine if the act of production is self-incriminating is very fact-specific, and seemingly identical factors between cases must be carefully analyzed within the context of each case. ${ }^{30}$ For instance, one factor that courts consider in deciding whether the act of producing the documents constitutes "testimony" or a mere "surrender" of knowledge is the extent of the government's specific knowledge of the documents in question. The lack of specificity of the government's knowledge or request may show that it is attempting a "fishing expedition" and using the defendant as the primary informant against himself. ${ }^{32}$ Alternatively, highly specific knowledge or requests by the government may show that it is using the defendant's act of production as a self-incriminating act of authentication by affirming possession and control of the documents. ${ }^{33}$

\section{B. The Collective Entity Doctrine}

Analyzing the Fifth Amendment privilege against selfincrimination becomes even more complex when the government subpoenas corporate documents because the Fifth Amendment privilege does not extend to corporations and instead only applies to natural persons. ${ }^{34}$ Under the collective entity doctrine, the corporation is considered to be an entity independent from the individuals it is comprised of and thus outside the scope of protection of the Fifth Amendment. ${ }^{35}$ Traditionally the collective entity doctrine has been jus-

29 Id at 40 ("The 'compelled testimony' that is relevant in this case is not to be found in the contents of the documents produced in response to the subpoena. It is, rather, the testimony inherent in the act of producing those documents.").

30 See Fisher, 425 US at 410 (stating that Fifth Amendment self-incrimination analysis may "depend on the facts and circumstances of particular cases").

31 Id at 411 (considering the sum total of the government's knowledge without the defendant's act of production), citing In re Harris, 221 US 274, 279 (1911). See also In the Matter of Grand Jury Empanelled March 19, 1980, 680 F2d 327, 335 (3d Cir 1982) (noting that the broad subpoenas issued by the government were an attempt to compensate for a lack of knowledge, effectively requiring the target of the subpoenas to become an informant against himself).

32 See, for example, Hubbell, 530 US at 43 (finding that the respondent was entitled to protection from grand jury's subpoena for broad categories of documents under the Fifth Amendment privilege against self-incrimiration, and noting that "we have no doubt that the constitutional privilege against self-incrimination protects the target of a grand jury investigation from being compelled to answer questions designed to elicit information about the existence of sources of potentially incriminating evidence").

33 See, for example, In re Grand Jury Subpoenas Duces Tecum Dated June 22, 1983 and June 22, 1983 ("Saxon Industries"), 722 F2d 981, 983 (2d Cir 1983) (finding that requests for documents the government already possessed could only be testimonial in nature).

34 Braswell v United States, 487 US 99, 105 (1988) (stating that, unlike an individual, "a corporation has no Fifth Amendment privilege").

35 See id at 102 (noting that "it is well established that such artificial entities are not protected by the Fifth Amendment"). 
tified by the state's power to regulate the entity to ensure that a corporation acts for the public good and within the limits of its stategranted charter. ${ }^{36}$ Thus, although an individual representing the corporation would be forced to respond to the subpoena duces tecum, the documents requested are the property of the corporation, and thus of a public nature, precluding the individual from invoking his personal privilege against self-incrimination.

The Supreme Court's jurisprudence has evolved from focusing on a property rights rationale to focusing on an agency rationale for the collective entity doctrine. ${ }^{38}$ An individual who is a representative of a group is not acting in his personal capacity when compelled by a subpoena to produce business records of that group even if the records might be personally incriminating. Under this line of reasoning, the Court has not limited the definition of a collective entity to a corporation, and has even applied it to a small partnership. ${ }^{39}$

Moreover, the Court has reasoned that enforcement of governmental regulations of corporate entities would be wholly ineffective without compelled production because the only way for a corporation to produce documents is through its representatives. ${ }^{40}$ If corporate representatives were allowed to assert their Fifth Amendment privilege against self-incrimination, proponents of the doctrine claim the government would be unable to gain possession of the information it needs for a successful investigation and prosecution.

Thus, employees or officers of a corporation act as agents of that corporation, a collective entity. As representatives of the corporation, these individuals may not refuse to produce documents because the

36 See Wilson v United States, 221 US 361, 383 (1911) ("[T]he corporation is a creature of the State. It is presumed to be incorporated for the benefit of the public. It receives certain special privileges and franchises, and holds them subject to the laws of the State and the limitations of its charter. Its powers are limited by law."). However, because such a rationale only covered corporations, when the Court later extended the doctrine to other organizations such as labor unions and partnerships, it justified the expansion by a "more general governmental need to regulate the affairs of economically powerful organizations." David N. Lathrop, Comment, The Collective Entity Doctrine and the Compelled Testimony Standard, 16 Hastings Const L Q 553, 557 (1989).

37 Wilson, 221 US at 378-80 (distinguishing between the privileges accorded private and public documents).

38 See Braswell, 487 US at 109 (noting that the "agency rationale undergirding the collective entity [doctrine] ... survives").

39 See, for example, Bellis v United States, 417 US 85, 95, 97 (1974) ("While small, the partnership here did have an established institutional identity independent of its individual partners ... [and] petitioner is holding the subpoenaed partnership records in a representative capacity.").

40 Id at 91 (stating that "[w]ere the cloak of the privilege to be thrown around these impersonal records and documents, effective enforcement of many federal and state laws would be impossible"), quoting United States v White, 322 US 694, 700 (1944).

41 See Bellis, 417 US at 90 (noting that "recognition of the individual's claim of privilege with respect to ... financial records ... would ... largely frustrate legitimate governmental regulation"). 
documents might be self-incriminating. ${ }^{42}$ Compelling production of documents by an individual in his capacity as representative of a corporation "does not invade his personal privacy or dignity" otherwise protected by the Fifth Amendment.

\section{The Roles of the Act of Production and Collective Entity Doctrines}

After Fisher, it was unclear whether the Court's holding signaled the abandonment of the collective entity doctrine, or if it was meant to fill another niche in this amorphous area of the law. Initially, the reliance of the Court on the act of production doctrine in Fisher led to a circuit split on which doctrine controlled the use of the Fifth Amendment privilege against self-incrimination by custodians of business records. Through its holdings in Braswell $v$ United States ${ }^{44}$ and United States $v$ Doe, the Court tried to clarify the distinctions between the two doctrines by focusing on the form of business.

In Doe, the Court held that the petitioner, as the owner of several sole proprietorships, could not be compelled to produce business documents. ${ }^{46}$ Relying on a district court's finding that the act of producing the documents would reveal incriminating information, the court concluded that the act of production doctrine shielded the defendant from turning over the records. In contrast, the petitioner in Braswell initially operated his business as a sole proprietorship, but eventually incorporated it.

The district court "rejected petitioner's argument that the collective entity doctrine does not apply when a corporation is so small that

42 See id at 88 (stating that "an individual cannot rely upon the privilege to avoid producing the records of a collective entity which are in his possession in a representative capacity, even if these records might incriminate him personally").

43 In re Grand Jury Subpoenas Duces Tecum Dated June 22, 1983 and June 22, 1983 ("Saxon Industries"), 722 F2d 981, 984, 986-87 (emphasis added) (remanding, however, for a determination of whether the compelled act of producing corporate documents was selfincrimination by a former employee and therefore unlawful). Note that a custodian of corporate records cannot be compelled to give oral testimony regarding those letters. As the Supreme Court has explained:

A custodian, by assuming the duties of his office, undertakes the obligation to produce the books of which he is custodian in response to a rightful exercise of the State's visitorial powers. But he cannot lawfully be compelled, in the absence of a grant of adequate immunity from prosecution, to condemn himself by his own oral testimony.

Curcio v United States, 354 US 118, 123-24 (1957). However, a representative may assert the Fifth Amendment privilege against self-incrimination in a personal capacity in order to shield himself from potential individual incrimination resulting from the act of production itself. See note 21 (discussing the attributed act theory).

44487 US 99 (1988).

45465 US 605 (1984).

46. Id at $606,612-14$.

47 Braswell, 487 US at 100-01. 
it constitutes nothing more than the individual's alter ego." ${ }^{48}$ In affirming the lower court, the majority in Braswell clearly distinguished the compelled testimony or act of production doctrine from the traditional collective entity doctrine by differentiating between custodians of business records for corporations and for other types of businesses, such as sole proprietorships. ${ }^{49}$ Braswell held that a representative of a corporation, although it was run essentially as a sole proprietorship, cannot assert the Fifth Amendment privilege against selfincrimination. ${ }^{30}$ The majority also made clear that Fisher had not replaced the collective entity doctrine with the act of production doctrine, and that the collective entity doctrine was still valid and continued to be based on an agency rationale.

It therefore seems that the distinguishing feature between Doe and Braswell is that the petitioner's business in Braswell was conducted through the corporate form, while the petitioner's business in Doe was conducted in a more informal fashion. The Court stated in Braswell that " $[\mathrm{h}] \mathrm{ad}$ petitioner conducted his business as a sole proprietorship, Doe would require that he be provided the opportunity to show that his act of production would entail testimonial selfincrimination." ${ }^{\text {,52 }}$ Corporate law differentiates between sole proprietorships and corporations on the basis that a sole proprietorship "involves neither the creation of a new separate entity nor the shifting of assets from one individual to another individual or entity." ${ }^{\text {,53 }}$ Thus, the Court pays due deference to the well-established principle of corporate law distinguishing between a corporation and a sole proprietorship. The collective entity doctrine applies in cases involving corporations and the act of production doctrine applies in cases involving sole proprietorships.

48 Id at 102. The decision in Braswell to apply the collective entity doctrine to such a small entity seems to be a logical extension of the Court's holding in Bellis $v$ United States that a threeperson partnership was still subject to the collective entity doctrine. Bellis, 417 US 85, 86, 101 (1974). Dicta in Bellis allude to the possible existence of a "Mom-and-Pop" exception, exempting a "small family partnership" or a partnership involving a "pre-existing relationship of confidentiality among the partners." Id at 101 . However, Justice Marshall, writing for the majority, noted that this exception would not apply to the partnership at issue because the defendant held the partnership's records, which were the partnership's property under state law, in a representative capacity. Id at $97-98,101$.

49 Braswell, 487 US at 104 (explaining the collective entity rule).

50 Id.

51 Id at 109 ("To be sure, the holding in Fisher ... embarked upon a new course of Fifth Amendment analysis.... [But the] agency rationale undergirding the collective entity [doctrine] ... survives.").

52 Id at 104.

53 Roger M. Ritt and Michael J. Nathanson, Choice of Business Entity, SC65 ALI-ABA 19, 21 (1998). 


\section{The COllective ENTITy AND ACT OF Production DOCTRINES IN THE CONTEXT OF FORMER EMPLOYEES}

The scope of the Fifth Amendment privilege against selfincrimination regarding former corporate employees and the production of corporate documents is ambiguous. The Court's decisions in Fisher and Braswell do not definitively establish the analysis for determining under what circumstances the privilege exists. Instead, it is unclear whether the content and the corporate nature of business documents continues to be relevant to determine whether a former employee is able to invoke his personal privilege against selfincrimination to avoid production of such documents. The Supreme Court last explicitly spoke on the issue of former officers and partners in the earlier part of the century, long before it shifted to the compelled testimony analysis of Fisher and Braswell. ${ }^{\text {s4 }}$ Thus, it is unclear whether the property rights and privacy rationales underlying those cases continue to survive today.

\section{A. The Context of Previously Dissolved Corporations}

In the earlier part of the previous century, the Supreme Court confronted the issue of the application of the Fifth Amendment privilege against self-incrimination in the context of former officers of dissolved corporations. ${ }^{35}$ The Court, relying on a property rights rationale, held that the dissolution of a corporation did not change the essential character of the corporation's books and papers. Thus, former officers were precluded from invoking the Fifth Amendment privilege against self-incrimination to resist the production of documents that "were still in existence and were still impressed with the incidents attending corporate documents." ${ }^{\text {,56 }}$ The dissolution of the corporation and possession by the former officers did not make the documents "any more privileged in the investigation of crime than they were before."

Over time, the Court's justification for the post-dissolution application of the corporate entity doctrine shifted from the property rights rationale to an agency rationale. In Bellis $v$ United States, ${ }^{38}$ the Court relied on an agency rationale to echo the earlier principle that the col-

54 See Grant v United States, 227 US 74, 79-80 (1913) (holding that the former sole shareholder of a defunct corporation must produce corporate records because the records were corporate rather than personal); Wheeler $v$ United States, 226 US 478, 489-90 (1913) (holding that the former officers of a dissolved corporation could constitutionally be compelled to produce corporate books and papers because the character of the records was corporate rather than personal).

55 See note 54.

56 Wheeler $v$ United States, 226 US 478, 490 (1913).

57 Id.

58417 US 85 (1974). 
lective entity doctrine continues to apply following dissolution. ${ }^{99}$ The Court made clear that each partner retained his representative status following the dissolution of the partnership, although the opinion primarily focused on the fact that the entity was a partnership, and not on the fact that the defendant was a former partner.

The Court's general shift in focus from the property rights rationale to the agency rationale for the collective entity doctrine supports the preservation of the Court's application of the collective entity doctrine to former partners and officers of dissolved corporations. Corporate law dictates that directors, officers, and controlling shareholders owe a fiduciary obligation to the corporation and minority shareholders. ${ }^{61}$ Under many state statutes, the fiduciary obligation continues whether the corporation is still in existence or has been dissolved, ${ }^{62}$ in order to preserve claims by creditors and wind up the corporation's final affairs. ${ }^{63}$ These statutes extend the life of the corporation for specific intervals following the date of dissolution. ${ }^{64}$ During these intervals, directors and officers owe fiduciary obligations to the corporation, and may even be held personally liable for distributing corporate assets to shareholders before satisfying creditors' claims. ${ }^{65}$ However,

$59 \quad$ Id at $97-99$.

60 Id at $96 \mathrm{n} 3$ ("[T]his Court's decisions have made clear that the dissolution of a corporation does not give the custodian of the corporate records any greater claim to the Fifth Amendment privilege.").

61 Franklin A. Gervurtz, Corporation Law 273 (West 2000) (stating that "directors and officers have a fiduciary duty to the corporation"). See also William Meade Fletcher, 3 Fletcher $C y$. clopedia of the Law of Private Corporations $\$ 837.50$ at 181-83 (Clark Boardman Callaghan perm ed 1994) (describing the fiduciary obligations of corporate directors and officers to the shareholders of a corporation).

62 See J. Ronald Trost and Roger G. Schwartz, Fiduciary Duties of Directors of Insolvent Corporations, SD24 ALI-ABA 87, 91 (1998). For examples of such state statutes, see Ga Code Ann $\S 14-2-1408$ (b) (Michie 2000); NM Stat Ann § 53-16-12(B) (Michie 2001); Alaska Stat $\S 10.06 .660 ;$ Cal Corp Code $\S 2001$ (West 1990).

63 Ann E. Conaway Stilson, Reexamining the Fiduciary Paradigm at Corporate Insolvency and Dissolution: Defining Directors' Duties to Creditors, 20 Del J Corp L 1, $66-67$ (1995) (describing states' enactment of "survival" period provisions that "extended the corporate life for a specific period post-dissolution for the purpose of prosecuting and defending suits").

64 Id. Note that the specific obligations of officers, directors, and controlling shareholders are also a matter of state statute. Because corporation laws vary from state to state, the exact nature of the fiduciary obligations of former employees, officers, and directors will also vary according to each state's corporations laws. See, for example, Fla Stat Ann $\$ 607.1405(2)$ (c) (West 2000); NY Bus Corp Law $\S 1006(a)(1)$ (McKinney 2001); Tex Bus Corp Act Ann art 7.12(B) (West 2000); Wash Rev Code § 23B.14.050(2)(c) (West 2001); Ariz Rev Stat Ann § 10-1405(B)(3) (West 2000); Neb Rev Stat $\S 21-20,155(2)$ (c) (Michie 2001); Ga Code Ann $\S 14-2-1408$ (b); NM Stat Ann $\S 53-16-12$ (B); Alaska Stat $\S 10.06 .660$; Cal Corp Code $\S 2001$. Note also that if the statutory rule in the state of incorporation is to assign an independent receiver to resolve the incomplete affairs of the corporation subsequent to dissolution, then the officer or director has a sound basis for arguing that he is no longer a representative of the corporation.

65 Stilson, 20 Del J Corp L at 66-67 (cited in note 63). Note that following dissolution and insolvency, the duty of corporate directors and officers shifts from shareholders to creditors. See Trost and Schwartz, SD24 ALI-ABA at 95 (cited in note 62). However, such a shift in focus is 
some state corporation laws limit directors' and officers' liabilities past this cut-off date.

\section{B. Compelling Former Officers and Employees to Produce Self-Incriminating Documents}

The Court's shift in focus from the contents of the requested documents to the act of production in recent years has led to confusion among the lower courts as to whether the contents-based privilege survives Fisher at all, or whether instead the foundation for all documentary subpoenas relies on the act of production. ${ }^{67}$ More specifically, the circuit courts disagree about the appropriate approach to the question of whether the privilege against self-incrimination may be invoked by a former officer or employee. The Second Circuit concluded that the representative status of any employee is terminated simultaneously with employment, ${ }^{68}$ whereas the Eleventh Circuit ruled that it is the character of the records sought that determines whether the collective entity doctrine continues to apply. ${ }^{69}$

\section{Cases against compelling former employees to produce potentially self-incriminating corporate records.}

The Second Circuit has repeatedly held that once an employee or officer is no longer employed at the company in question, he can no longer serve as a representative of the company. ${ }^{70}$ In In re Grand Jury

tangential to the main principle of corporate law of a continuing fiduciary duty postdissolution, and thus need not be considered here.

66 Stilson, 20 Del J Corp L at 66-69 (cited in note 63) (explaining that some state statutes "ostensibly curtail directorial and shareholder liability after the statutory cut-off date").

67 See, for example, Anne Marie DeMarco and Elisa Scott, Note, Confusion among the Courts: Should the Contents of Personal Papers Be Privileged by the Fifth Amendment's SelfIncrimination Clause?, 9 St John's J Legal Commen 219, 222 (1993) (noting that "[a] need has therefore arisen for the Supreme Court to clearly state whether a contents-based privilege exists today").

68 In re Grand Jury Subpoenas Duces Tecum Dated June 22, 1983 and June 22, 1983 ("Saxon Industries"), 722 F2d 981, 986-87 (2d Cir 1983). The Third and Ninth Circuits have developed a jurisprudence parallel to the Second Circuit's in this area. However, neither court has analyzed the issue in as profound a manner. For instance, in United States v McLaughlin, 126 F3d 130, 134 ( $3 \mathrm{~d}$ Cir 1997), the court held that compelling former corporate custodians to produce documents would violate their Fifth Amendment privilege against self-incrimination. The Ninth Circuit explicitly stated that "the court follows the Second Circuit's decision in [Saxon Industries], ... and holds that the collective entity rule does not apply to a former employee of a collective entity who is no longer acting on behalf of the collective entity." In re Grand Jury Proceedings, 71 F3d 723, 724 (9th Cir 1995).

69 In re Grand Jury Subpoena Dated Nov 12, 1991, 957 F2d 807, 812 (11th Cir 1992). The D.C. Circuit has adopted the reasoning of the Eleventh Circuit in the context of former government officials. See In re Sealed Case (Government Records), 950 F2d 736, 739-41 (DC Cir 1991) (holding that government records, as well as corporate records, cannot be the subject of a former federal official's assertion of this Fifth Amendment privilege against self-incrimination).

70 See In re Grand Jury Subpoenas Duces Tecum Dated June 22, 1983 and June 22, 1983 
Subpoenas Duces Tecum Dated June 13, 1983 and June 22, 1983 ("Saxon Industries"), the court stated: "Under Fisher the standard is not the potential incriminating nature and contents of the documents subpoenaed but whether their mere production would itself tend to incriminate the possessor." ${ }^{12}$ The court explained the case of a present employee:

[T] here would rarely be any dispute over the possession when the person subpoenaed is required to respond in his representative capacity. In producing records as an officer of the company he would not be attesting to his personal possession of them but to their existence and possession by the corporation.." ${ }^{33}$

In contrast, in the context of a former employee of a corporation, the Second Circuit reasoned, the act of production may serve as a confirmation of the defendant's personal possession of the documents requested. His terminated status as an employee, and representative, of the corporation might imply that his possession of the documents was wrongful, and the act of production might be self-incriminating to the defendant as an individual. ${ }^{74}$

In Saxon Industries, the subpoenaed witness was the target of the grand jury investigation. ${ }^{75}$ The Second Circuit remanded for a determination of whether the compelled production (rather than the contents of the documents) would be self-incriminating. The court reasoned that production might prove possession and "enable the government to argue in any criminal proceeding against him that his removal of the documents from the company's files amounted to a tacit admission that he had ... absconded with them because he believed they were 'smoking gun' evidence of his guilt.,

("Saxon Industries"), 722 F2d 981, 986-88 (2d Cir 1983) ("Once the officer leaves the company's employ ... he no longer acts as a corporate representative but functions in an individual capacity in his possession of corporate records." The court remanded the case to determine whether the act of production was self-incriminating.); In re Three Grand Jury Subpoenas Duces Tecum Dated Jan 29, 1999 ("Grand Jury I"), 191 F3d 173, 181, 183-84 (2d Cir 1999) (reaffirming Saxon Industries after Braswell so that former employees are no longer corporate representatives and may assert the Fifth Amendment privilege against the act of production).

71722 F2d 981 (2d Cir 1983).

72 Id at 986 . However, this case predates Braswell.

73 Id.

74 Id at 986-89 (remanding to the district court for a determination of whether the act of production was self-incriminating).

75 See id at 982. Another distinguishing characteristic of Saxon Industries is that (according to the former employee) most, if not all, of the documents requested by the government were duplicates of documents that the government already possessed. Id at 983 . Thus, although the defendant in Saxon Industries may have misappropriated corporate records into his own possession, his possession of the documents was not sufficient to infringe upon his Fifth Amendment privilege against self-incrimination. See id at $986-88$.

76 Id at 987. 
In In re Grand Jury Subpoenas Duces Tecum Dated Jan 29, 1999 ("Grand Jury I"), the Second Circuit reaffirmed its Saxon Industries holding $^{78}$ and held that its decision in Saxon Industries survived Braswell. ${ }^{79}$ The majority held:

In the absence of legal authority to the effect that a former employee remains an agent of the corporation, or any evidence that the corporation and the individual intended to maintain an agency relationship, the foundation upon which Braswell reststhat one who is currently employed by the corporation holds documents as an agent in a custodial capacity so that it is actually the corporation that is producing the records - is removed. ${ }^{80}$

Moreover, the court disputed the contention that characterizing former employees of a corporation as no longer representatives of that corporation would create incentives for employees to leave with documents to avoid producing them. ${ }^{81}$ The court found that there have been "few reported incidents" of employees taking advantage of this rule. Additionally, the court reasoned that sanctions for theft and obstruction of justice, and the government's ability to recover the documents through other means, such as a search warrant, ${ }^{84}$ would eliminate the perverse incentives for employees.

2. Cases requiring former employees to produce potentially selfincriminating corporate records

In contrast to the Second Circuit, the Eleventh Circuit held in In re Grand Jury Subpoena Dated Nov 12 ("Grand Jury II") that the collective entity doctrine requires former employees to produce documents relating to their former employers. ${ }^{86}$ The Eleventh Circuit

$77 \quad 191$ F3d 173 (2d Cir 1999).

78 Id at 181 (describing Saxon Industries as "good law").

79 Id.

80 Id

81 Id at 182 (rejecting the government's argument that the decision would "create[] a perverse incentive for an employee to leave the corporation with the documents in his custody rather than comply with his legal obligation to produce the documents").

82 Id.

83 Id.

84 Id at 183 (noting that "there is nothing in the Fifth Amendment that prevents the government from proceeding to recover the documents itself, without compelling their production by the person in possession, by means of a search warrant").

85957 F2d 807 (11th Cir 1992).

86 Id at $812-13$ (holding that a former corporate official whose employment was terminated after he acquired copies of corporate documents was required to produce those documents under the collective entity doctrine). 
focused on the nature of the documents to establish the representative relationship of the former employee to the corporation.

In Grand Jury II, the court required a former corporate official, who was terminated following a change in control, to produce documents held in a personal capacity under the collective entity doctrine. Relying on early Supreme Court precedent, ${ }^{88}$ the court focused primarily on the nature and contents of the documents requested rather than on the representative status of the former employee. ${ }^{89}$ The court held: "It is the immutable character of the records as corporate which requires their production and which dictates that they are held in a representative capacity. Thus, the production of such documents is required regardless of whether the custodian is still associated with the corporation or other collective entity."

Thus, some courts focus on the potentially incriminating nature of the act of production by former employees and some courts focus on the creation of the documents by the collective entity. It is unclear which doctrine controls whether a former employee is able to invoke his personal privilege against self-incrimination to avoid production of such documents.

\section{A NEW APPROACH}

This Comment proposes a new approach to the application of the collective entity doctrine to the production of corporate documents in the context of former corporate employees. ${ }^{91}$ This approach focuses on the representative status of the former employee and looks to principles of corporate law to determine whether a representative relationship continues to exist following the termination of employment. More specifically, this approach considers the distinguishing characteristics of employees in the contexts of a previously dissolved corporation, former employees of a corporation with a continuing existence, and former employees of an acquired or merged corporation.

In recent years, the Court has shifted away from the previous property rights and privacy rationales for determining the validity of subpoenas duces tecum. ${ }^{2}$ The underlying agency rationale for the col-

87 Id at 812 ("It is the immutable character of the records as corporate which requires their production and which dictates that they are held in a representative capacity.").

88 See note 54.

89 Grand Jury II, 957 F2d at 811 (noting that "the Second Circuit [in Saxon Industries] did not consider the Supreme Court's prior decisions to the contrary in Wheeler and Grant").

90 Id at 812.

91 ' $[\mathrm{T}]$ he term 'employee' in both Model Business Corporation Acts, includes officers but not directors, although a director may accept duties which make that director also an employee." William Meade Fletcher, 2 Fletcher Cyclopedia of the Law of Private Corporations $\$ 266$ at 12 (West perm ed 1998). See also MBCA $\$ 1.40(8)$ (ABA 1984).

92 Neville S. Hedley, Comment, Who Will Produce Corporate Documents? Case Comment 
lective entity doctrine focuses on the nature of the relationship between the former employee and the corporation. The Court has held that if the individual is a member of an independent corporate entity, then he is unable to assert his personal privilege against selfincrimination because of his representative relationship with the corporation. ${ }^{93}$ Fisher and Doe make clear that the Court has moved to an analytical framework that focuses on the potentially incriminating nature of the act of production, rather than on the contents of the documents themselves. ${ }^{94}$

This approach is echoed by the Second Circuit's reasoning in finding that the representative status of an employee or officer is terminated following the conclusion of his employment, ${ }^{95}$ using the clearly demarcated relationships created by corporate law to determine when a representative relationship exists. This Comment suggests that courts determine whether a representative relationship still exists by looking to principles of corporate law that create and control such employment and agency relationships. Specifically, in the context of former employees, this Comment proposes looking to whether the former employee continues to have a fiduciary obligation to the corporation in order to determine representative status.

The Court's precedents from the earlier part of the twentieth century are consistent with corporate law principles. Although the Court's reasoning focused on the property rights and privacy rationales that were prevalent at the time, ${ }^{96}$ the Court's shift of focus to the compelled testimony standard in Fisher shows that such justifications are no longer prevalent in this area of the law. Nevertheless, their holdings should be preserved since they are consistent with the more modern agency rationale of the collective entity doctrine.

The fiduciary obligations of corporate employees are determined by the law of the state of incorporation. ${ }^{97}$ Typical corporate employees

of In re John Doe Grand Jury Investigation, 30 New Eng L Rev 141, 151-54 (1995) (noting that the Court's holding in Bellis "clearly signaled the shift from a property rights rationale, to a privacy rationale for determining if the privilege could be invoked" and that the Court's decision in Fisher moved from focusing on the privacy rationale to the compelled testimony standard).

93 Braswell, 487 US at 109-10 (explaining that because the custodian of corporate records holds them in a representative capacity, his act of producing them is attributed to the corporation and is therefore unprotected by the Fifth Amendment).

94 Id at 109 ("In Fisher and Doe, the Court moved away from the privacy-based collective entity rule, replacing it with a compelled-testimony standard under which the contents of business documents are never privileged but the act of producing the documents may be.").

95 See Part II.B.1.

96 See note 54.

97 Fletcher, 3 Fletcher Cyclopedia $\$ 840$ at 213 (cited in note 61) ("The determination officer's fiduciary duty to the corporation and its shareholders is generally governed by the law of the state of incorporation."). 
do not owe a fiduciary obligation to the corporation, ${ }^{98}$ but they are still considered agents of the corporation. ${ }^{99}$ Corporate directors and officers do owe a fiduciary obligation to the corporation. ${ }^{100}$ While at common law the fiduciary obligations of corporate officers and directors terminate along with employment if the corporation continues to exist, ${ }^{101}$ most state statutes extend the fiduciary obligations of directors postdissolution in order to wind up the corporation's remaining affairs. ${ }^{102}$

In the context of the collective entity doctrine, representative status should be defined by the clearly demarcated fiduciary obligations determined by state corporate law. Therefore, the collective entity doctrine should cease to apply following an employee or director's termination, and instead the act of production doctrine alone should control to protect former employees' and directors' Fifth Amendment privilege against self-incrimination. This reasoning should hold for corporations that continue in existence either in their original forms or for corporations that undergo a change in control, because of the termination of the representative status of directors and employees in both instances.

This mode of analysis is contrary to the Eleventh Circuit's approach. However, this analysis stays truer to the rationale underlying the collective entity doctrine - that is, a representative of a collective entity cannot assert a personal privilege against self-incrimination.

98 Id $\S 846$ at 226 (stating that "the concept of fiduciary duty is generally not applicable to typical employees"). See, for example, Southeast Consultants, Inc v McCrary Engineering Corp, 246 Ga 503, 273 SE2d 112, 115-16 (1980) (holding that a state statute imposing liability on directors and officers for appropriating business opportunities in violation of their duties did not apply to typical employees). Consider Cameco, Inc v Gedicke, 157 NJ 504, 724 A2d 783, 789, 791 (1999) (noting that officers, directors, and key executives owe a higher duty of loyalty to their employers than lower level employees such as production line workers).

99 See Fletcher, 2 Fletcher Cyclopedia $\$ 266$ at 10-11 (cited in note 91) ("There is a marked distinction between the officers who manage the affairs of a corporation, and its mere agents... An agent is not an employee.").

100 Fletcher, 3 Fletcher Cyclopedia $\$ 837.50$ at 181 (cited in note 61) ("Directors stand in a fiduciary relationship to the corporation and its shareholders.").

101 Id $\S 860$ at 275 ("When a corporate officer ceases to act as such, either because of his or her resignation or removal from office, or because of the insolvency of the corporation, the fiduciary relationship ceases."). See, for example, Standage v Planned Investment Corp, 160 Ariz 287, $772 \mathrm{P} 2 \mathrm{~d} 1140,1144$ (Ariz App 1986) (recognizing the general rule that a corporate officer's fiduciary duty ceases at his resignation or removal, but finding an exception to this rule applicable in this particular case); Microbiological Research Corp v Muna, 625 P2d 690, 695 (Utah 1981) ("When a corporate officer ceases to act as such, because of his resignation or removal, the fiduciary relationship ceases.").

102 Fletcher, 19 Fletcher Cyclopedia $\$ 3: 150$ at 453 (cited in note 9) (noting that "statutes will usually provide that, upon the dissolution, the directors of the corporation shall have charge of the work of liquidation and distribution").

103 Braswell, 487 US at 109-10 (explaining that a custodian of corporate documents holds them "in a representative rather than a personal capacity," so the act of production is attributed to the corporation and therefore unprotected by the Fifth Amendment). 
Courts should not attempt to apply the collective entity doctrine until they have concluded that the individual in fact is a representative of the collective entity. Therefore, courts should rely on the principles of corporate law to determine when an individual retains his status as a representative of a corporation, and when that status, in fact, has been terminated.

\section{A. Previously Dissolved Corporations}

In the context of previously dissolved corporations, the Court's prior holdings are consistent with the relevant principles of corporate law, ${ }^{104}$ and based on these holdings, courts should find that the collective entity doctrine continues to apply to former partners and officers of a corporation. However, the Court has not dealt specifically with the issue of former employees who are terminated as a result of dissolution. Because of key distinctions between employees and officers, the collective entity doctrine should not apply to employees terminated through dissolution of the corporation.

There are key distinctions between typical employees of a corporation and directors and officers of a corporation. ${ }^{105}$ The primary distinction is that employees do not owe a fiduciary obligation to the corporation during or following their employment, ${ }^{106}$ and have no continuing duties to a corporation following their termination, ${ }^{107}$ unlike directors and officers. ${ }^{108}$ Moreover, following termination of employment, the corporation has no continuing vicarious liability. ${ }^{100}$

Consequently, the representative relationship between typical employees and the corporation should terminate simultaneously with their employment, and consistent with the agency rationale, the collective entity doctrine should cease to apply once the representative relationship has ended. The collective entity doctrine may continue to apply to officers and directors of a previously dissolved corporation, but not to previous employees of the corporation.

104 See text accompanying notes 97-102.

105 Fletcher, 2 Fletcher Cyclopedia § 266 at 265 (cited in note 91) ("There is a marked distinction between the officers who manage the affairs of a corporation and its mere [ ] [employees].").

106 See note 98 and accompanying text.

107 William A. Klein and John C. Coffee, Jr., Business Organization and Finance: Legal and Economic Principles 16 (Foundation 2000) (noting that the duties and obligations of an employee only exist for the duration of the employment contract).

108 See id.

109 See id at 18. 


\section{B. Resignation or Removal}

The act of production doctrine should apply to former employees whose employment was terminated as a result of resignation or removal because it is clear that they no longer act as representatives of their former employer. Principles of corporate law dictate that employees of a corporation with a continuing existence who resign or are removed no longer have any fiduciary obligation to their former employer, ${ }^{10}$ and no longer hold the powers associated with their former position. ${ }^{111}$ Thus, such employees do not serve as representatives of their former employer past the termination of their employment. ${ }^{112}$

The Eleventh Circuit relied on the content and nature of the documents requested in finding that a former corporate officer who was removed from his position was still obligated to produce corporate records on demand. ${ }^{113}$ However, the court relied on precedents that predate the Supreme Court's shift to the compelled testimony standard in Fisher. ${ }^{114}$ The focus of these earlier precedents on the contents of the documents was based on the property rights and privacy rationales ${ }^{115}$ that were later superseded by the Court's compelled testimony standard in Fisher. The Court's primary inquiry in Fisher focused on whether the individual's right against self-incrimination was being infringed by compelling the act of production. ${ }^{116}$ Thus, while the Eleventh Circuit's criticism of the Second Circuit's failure to look to these precedents is valid, it also fails to recognize the significantly different approach that the Court took in Fisher. ${ }^{117}$ Instead, the court looks to the previously eschewed property rights and privacy rationales to hold that the content and nature of the documents controls whether the collective entity doctrine applies to former employees. ${ }^{11}$

110 See note 101 and accompanying text.

111 See, for example, Maine Products Co v Alexander, 115 AD 109, 111, 100 NYS 709 (1906) ("If the resolution dismissing the defendant was authorized, no act of the manager will bind the company. Indeed, it is probable that the act of the company in dismissing the defendant ... would, whether justified or not, terminate his power to bind the company.").

112 See Fletcher, 3 Fletcher Cyclopedia $\$ 994$ at 704-05 (cited in note 61) (stating that "persons are liable as corporate officers, either under statute creating the liability or independent of statute, and without regard to who is seeking to enforce the alleged liability, only where they were officers at or during the time of the act or omission relied on as creating liability").

113 Grand Jury II, 957 F2d at 812-13. See notes 85-90 and accompanying text.

114 Id at 810-11, citing Wheeler v United States, 226 US 478, 490-91; Grant v United States, 227 US 74, 79-80 (1913); and Bellis v United States, 417 US 85, 88, 96 n 3.

115 See text accompanying notes 36-38.

116 Fisher, 425 US at 409 (addressing the question "what, if any, incriminating testimony within the Fifth Amendment's protection, is compelled by a documentary summons").

117 Grand Jury II, 957 F2d at 811 (failing to include Fisher meaningfully in the analysis).

118 Id at 812 ("It is the immutable character of the records as corporate which requires their production."). 
After Fisher, it seems clear that the act of production doctrine renders the contents of business documents irrelevant to determining the validity of subpoenas duces tecum. ${ }^{119}$ Moreover, since the collective entity doctrine primarily turns on the agency rationale, it seems that the existence of a representative relationship should be the basis for determining whether the collective entity doctrine continues to apply past termination of employment. After Fisher, the threshold question in determining whether the collective entity doctrine applies as an exception to the broader act of production doctrine is whether the defendant is, in fact, a representative of the collective entity. Thus the analysis focuses not on the creation or contents of the documents, but the subsequent chronological step-the act of production. ${ }^{120}$ Such an analysis focuses on the "communicative or noncommunicative nature of the arguably incriminating disclosures sought to be compelled." Therefore, relying solely on the content and nature of the documents sought ignores the basic rationale for the exception. ${ }^{122}$

The application of the act of production doctrine to determine the validity of subpoenas duces tecum targeted at former employees who have either resigned or been removed would not relieve those former employees from liability for the wrongful acts they may have committed during the course of their employment. Rather, this approach recognizes that a subpoena directed at a former employee is more likely to target the employee as an individual than as a representative of the corporation. ${ }^{123}$ The application of the act of production doctrine rather than the collective entity doctrine would protect the former employee from the incriminating act of production-affirming his personal possession of the documents requested, which together with his terminated status as employee and representative of the corporation, implies that his possession of the documents was wrongful. ${ }^{12}$

119 Braswell, 487 US at 109 ("In Fisher and Doe, the Court moved away from the privacybased collective entity rule, replacing it with a compelled-testimony standard under which the contents of business documents are never privileged but the act of producing the documents may be.").

120 See Lewis R. Katz and Paul C. Giannelli, 2 Katz Giannelli Criminal Law $\$ 41.5$ at 101-04 (West 1996) (describing the Court's rejection of the privacy rationale and adoption of the act of production rationale).

121 In re Grand Jury Matter, 768 F2d 525, 528 (3d Cir 1985) (en banc) ("[Fisher and Doe] make the significant factor, for the privilege against self-incrimination, neither the nature of the entity which owns documents, nor the contents of the documents, but rather the communicative or noncommunicative nature of the arguably incriminating disclosures sought to be compelled.").

122 See Mosteller, 73 Va L Rev at 49-50 (cited in note 1) (discussing rationales for the artificial entity exception to the act of production analysis).

123 See text accompanying notes 74 and 76.

124 See text accompanying note 74 . 
Moreover, this approach does not significantly impede the government's ability to obtain the requested documents. If the government is precluded from obtaining the documents because of the incriminating nature of the act of production, it may have independent criminal claims against the former employees for theft or obstruction of justice, which would also result in the production of the documents. ${ }^{125}$ Another possibility is that the government may compel production of the documents by granting the individual immunity. ${ }^{126}$ The corporation may then be prosecuted because the Fifth Amendment only extends protection to natural persons. The former employee who is granted immunity may also be prosecuted if the government is able to obtain the information found in the subpoenaed documents independently. $^{127}$

\section{Change in Control}

Once a company has been acquired or merged into another company, litigation can no longer be brought against that company because its legal identity has been subsumed or eliminated by a consolidation action. ${ }^{128}$ Thus former employees, due to removal, resignation, or the consolidation itself, can no longer be required to maintain a representative relationship with that former corporation because the corporation has ceased to exist. Unlike in the context of dissolution, there are no remaining fiduciary obligations by any former employees, officers, or directors, regardless of their position. Instead, the new company or the acquiring company undertakes these obligations, and a new custodian maintains the corporate records. ${ }^{129}$ Therefore, the collective entity doctrine should not apply in this context, and courts should focus on the application of the act of production doctrine. ${ }^{130}$

125 See text accompanying notes 83-84.

126 For a general discussion of the act of production and immunity, see Kenneth J. Melilli, Act-of-Production Immunity, 52 Ohio St L J 223 (1991).

127 See id at 246 (noting that "the protection afforded by the grant of act-of-production immunity is potentially illusory").

128 Niesz v Gorsuch, 295 F2d 909, 913-14 (9th Cir 1961) (concluding that on completion of a merger the merged company "lost its capacity to be sued as a party defendant," but the surviving corporation could be joined as a defendant); Heit v Tenneco, Inc, 319 F Supp 884, 886-88 (D Del 1970) (denying standing to a former stockholder of a merged corporation who was attempting to bring a derivative suit on its behalf).

129 See Stephen M. Flanagan, Charles R.P. Keating and J. Jeffrey Reinholtz, 15 Fletcher $C y$ clopedia of Corporations $\$ 7089$ (West 1997 \& Supp 1999).

130 The pragmatic difference between the application of these two doctrines means that the government will be able to obtain all of the documents with respect to a dissolved corporation, but will need to attribute the act of production itself to the entity instead of an individual, whereas in the context of a corporation with a continuing existence, the government may not be able to get all of the documents because of the application of the act of production doctrine and the ability of the former employee to assert his Fifth Amendment privilege. 
As a practical consideration, the situation of consolidation differs markedly from dissolution, because in a consolidation the corporation continues to exist through new representatives under a new identity as a collective entity. ${ }^{131}$ Former employees may still be held personally liable for their actions during the time of their employment because they no longer act in a representative capacity for their former employer. Because the terminated employee is no longer a representative of the corporation, government requests for documents in the context of corporate consolidation are more likely to be targeted at incriminating the individual. Therefore, these individuals should be afforded the full Fifth Amendment protections. ${ }^{132}$ Although in some ways a company that disappears in a consolidation is analogous to one that dissolves, the fundamental difference is a lack of any continuing fiduciary obligation on the part of the former employees, officers, or directors of an absorbed company, unlike the continuing obligation in the case of a dissolved company. Thus, the need to protect the privilege against self-incrimination is the same as in the context of a company whose identity is lost in consolidation, and the act of production doctrine should apply in this context as well.

The Eleventh Circuit's focus on the content and nature of the documents requested rather than the representative status of the former employee for the purposes of the collective entity doctrine ${ }^{133}$ fails to incorporate all of the subtle differences between the various circumstances that may result in termination of employment. However, the Court's shift to the compelled testimony standard and away from the contents of the documents themselves suggests that the application of the collective entity doctrine turns on the nature of the relationship of the individual with the corporation rather than the contents of the documents requested. Deference to corporate law principles in determining whether a representative relationship continues to exist past termination may be helpful in analyzing whether a representative relationship exists.

\section{CONCLUSION}

Uncertainty remains as to whether the content and nature of documents requested by a subpoena duces tecum continues to be relevant in the context of a former employee. More specifically, the applicability of the collective entity doctrine to former employees is ambiguous.

131 See Flanagan, Keating, and Reinholtz, 15 Fletcher Cyclopedia of Corporations $\S 7069$ (cited in note 129).

132 Consider Saxon Industries, 722 F2d at 987 (explaining why the act of production might be self-incriminating to the individual). See also text accompanying notes 74 and 76 .

133 See note 90 and accompanying text. 
The collective entity doctrine turns on the notion that a representative relationship exists between an employee and his corporate employer, thus precluding the individual from invoking his personal privilege against self-incrimination to refuse the production of requested corporate documents. This Comment seeks to introduce principles of corporate law to determine whether a representative relationship continues to exist between a former employee and a corporation and proposes that the collective entity doctrine should cease to apply when a former employee's representative status is terminated with employment. Thus, when a representative relationship has terminated, the act of production doctrine should apply to protect the individual's Fifth Amendment privilege against self-incrimination and courts and prosecutors should look to alternative means for obtaining the information they seek. 